\title{
PENGARUH CITRA MEREK, PERSEPSI HARGA DAN \\ KUALITAS PRODUK TERHADAP KEPUTUSAN \\ PEMBELIAN KONSUMEN NPK MUTIARA DI \\ UD.BARELANG TANI JAYA BATAM
}

\author{
Lukmanul Hakim¹, Rinjani Saragih ${ }^{2}$
}

Universitas Riau Kepulauan, Batam, Indonesia ${ }^{1}$

Universitas Riau Kepulauan, Batam, Indonesia ${ }^{2}$

Email : lukmann14@gmail.com

\begin{abstract}
ABSTRAK
Penelitian bertujuan untuk mengetahui pengaruh Citra Merek, Persepsi Harga dan Kualitas Produk terhadap Keputusan Pembelian pupuk NPK Mutiara di UD. Barelang Tani Jaya Batam. Penelitian ini dilakukan dengan pendekatan survey yang terdiri dari variabel Citra Merek $\left(\mathrm{X}_{1}\right)$, Persepsi Harga $\left(\mathrm{X}_{2}\right)$, Kualitas Produk $\left(\mathrm{X}_{3}\right)$ dan Keputusan Pembelian $(\mathrm{Y})$. Sampel yang digunakan dalam penelitian ini berjumlah 58 responden. Pernyataan diberikan dengan menggunakan kuesioner yang didistribusikan melalui teknik Random Sampling dan metode analisis data yang digunakan adalah uji validitas, uji reliabilitas, uji asumsi klasik, dan analisis regresi berganda. Data yang terkumpul melalui kuesioner diolah dengan menggunakan aplikasi Program Statistical Product and Service Solution (SPSS) versi 20. Hasil penelitian menunjukkan bahwa nilai $\mathrm{t}_{\text {hitung }}$ untuk variabel citra merek sebesar 9,962 dan tingkat signifikan 0,000, nilai $\mathrm{t}$ hitung untuk variabel persepsi harga sebesar 52,693 dan tingkat signifikan 0,000 sementara nilai $\mathrm{t}$ hitung untuk variabel kualitas produk sebesar 40,089 dengan tingkat signifikan 0,000 yang lebih kecil dari 0,05. Dalam penggunaan Uji Parsial (T), terdapat pengaruh positif dan signifikan pada variabel Persepsi Harga (X2), hal ini dikarenakan nilai $\mathbf{t}$ hitung 52,693 $>\mathbf{t}$ tabel 1,672 dan tingkat signifikannya adalah 0,000 $<0,05$. Jadi terdapat hasil yang positif dan signifikan dari variabel citra merek, persepsi harga dan kualitas produk terhadap keputusan pembelian pupuk NPK Mutiara di UD. Barelang Tani Jaya Batam dan ketiga variabel tersebut memiliki hubungan yang besar dalam keputusan pembelian pupuk NPK Mutiara di UD. Barelang Tani Jaya batam.
\end{abstract}

Kata Kunci : Citra Merek, Persepsi Harga, Kualitas Produk, Keputusan Pembelian

\section{PENDAHULUAN}

\subsection{Latar Belakang Masalah}

Memasuki era globalisasi menuju Masyarakat Ekonomi Asean (MEA), memungkinkan satu negara menjual barang dan jasa dengan mudah sehingga persaingan akan semakin ketat. Banyaknya usaha yang ada semakin membuat banyak perusahaan tertarik dalam bersaing. 
Untuk dapat memenangkan persaingan dalam bisnis, pelaku bisnis harus merencanakan strategi-strategi pemasaran untuk memuaskan keinginan pelanggan.

Ketatnya persaingan dalam dunia usaha menuntut setiap perusahaan untuk dapat memenuhi kebutuhan konsumen serta berusaha untuk menciptakan suatu produk yang mempunyai keunggulan dan menciptakan produk yang berbeda dapat menjadi strategi yang efektif bagi perusahaan dalam memeberikan penawaran produk yang inovatif dan berkualitas sehingga tercapai suatu kepuasan masingmasing pihak.

Pertumbuhan ekonomi di era globalisasi ini menuntut tidak hanya perusahaan yang bergerak dalam bidang industri barang maupun jasa, namun kini Usaha Mikro Kecil Menengah (UMKM) juga harus mampu meningkatkan kompetisinya untuk dapat bersaing merebut pangsa pasar.UKM di Indonesia telah terbukti memberikan kontribusi signifikan terhadap nilai tambah untuk perekonomian Negara dan telah memberikan peluang kerja yang sangat besar.

Ada beberapa jenis UKM (Usaha Kecil Menengah) yang sedang berkembang pesat di kota Batam, salah satunya adalah UD.Barelang Tani Jaya. UD. Barelang Tani Jaya merupakan sebuah toko yang menyediakan dan menjual segala jenis benih tanaman pertanian lebih khususnya tanaman hortikultura dan obat tanaman.

Selain jenis tanaman hortikultura, UD.Barelang Tani Jaya juga menyediakan berbagai jenis pupuk organik maupun pupuk kimia serta jenis herbisida lainnya. Dengan adanya toko pertanian seperti ini akan membuat para petani lebih mudah untuk mendapatkan keperluan yang dibutuhkan dalam proses pengolahan pertanian mulai dari tahap olah tanah, penanaman, perawatan hingga pasca panen. Seiring berjalannya waktu. UD. Barelang Tani Jaya selalu menawarkan produk-produk yang terbaru yang diproduksi oleh produsen pertanian dan produk yang ditawarkan juga memiliki fungsi dan keunggulan yang sama, hanya saja ada pergantian merek dan kemasan yang berbeda dan lebih menarik perhatian para petani.

Produk yang berkembang dipasaran saat ini telah mengalami banyak sekali perkembangan, sehingga membuat jumlah produk menjadi semakin bertambah dan muncul produsen baru di pasar membawa dampak berbagai aspek, persaingan merupakan salah satu aspek yang paling profesional saat ini yang mengakibatkan produsen haruslah lebih efektif dalam menentukan produk yang akan dihasilkan.

Adapun strategi pemasaran yang tepat dan terencana dalam perusahaan yaitu dengan cara pencitraan merek yang baik dibenak konsumen dan kualitas produk yang berkualitas (Lasander, 2013). Merek merupakan sebuah nama, istilah, tanda , lambang, atau desain atau kombinasi dari semua ini, yang menunjukkan identitas pembuat atau penjual produk atau jasa. Dengan semakin dikenalnya sebuah merek, maka berdampak pada persepsi dan keyakinan dari konsumen atas produk tersebut sehingga dapat membentuk sebuah citra (image). Berdasarkan pernyataan ini, penulis termotivasi untuk meneliti salah satu produk pertanian yang dipasarkan di toko UD. Barelang Tani Jaya dengan merek NPK Mutiara.

NPK Mutiara adalah sebuah terobosan produk yang banyak dipasarkan di berbagai toko pertanian yang mana produk ini merupakan suplemen penyubur tanaman yang baik digunakan oleh petani untuk meningkatkan produksi panen, dan produk ini juga aman diaplikasikan dalam segala musim. NPK Mutiara juga 
merupakan sebuah produk yang sudah memiliki izin legal dari KEMTAN dan memiliki nomor pendaftaran yang sah sehingga aman untuk dipasarkan di beberapa toko pertanian khususnya UD.Barelang Tani Jaya. Pupuk NPK Mutiara memiliki beberapa jenis perbedaan baik kandungan unsur hara, warna dan juga kemasan. Berikut daftar nama produk NPK Mutiara yang tersedia di UD.Barelang Tani Jaya Batam:

1.NPK Mutiara 16.16.16

2.NPK Mutiara Grower 15.09.20

3.NPK 15.15.15 (nitrophoska)

Dengan adanya jenis produk yang bervariasi seperti yang tertera diatas dengan jaminan kualitas produk yang sudah dimiliki oleh NPK Mutiara membuat petani lebih percaya dan yakin pada produk yang akan mereka pergunakan.

Citra Merek merupakan asosiasi yang aktif di memori ketika ketika seseorang berfikir tentang merek tertentu (Shimp, 2010). Citra Merek dapat diartikan sebagai persepsi tentang merek yang tercermin oleh asosiasi merek diadakan pada memori konsumen. Citra Merek terdiri dari pengetahuan dan keyakinan konsumen tentang merek. Konsumen yang memiliki persepsi positif tentang suatu merek, berarti merek tersebut memberikan pesan dibandingkan dengan merek pesaing.

Harga merupakan salah satu penentu keberhasilan suatu perusahaan karna harga menentukan seberapa besar keuntungan yang akan dipeoleh perusahaan dari penjualan produknya baik berupa barang maupun jasa. Harga juga merupakan salah satu faktor kedua yang mempengaruhi keputusan pembelian dan kepuasan pelanggan dan faktor penting dalam perusahaan untuk mendapatkan laba. Setiap pelaku berusaha menetapkan harga yang terjangkau agar dapat lebih unggul dari pesaingnya. Dengan adanya kebijakan harga dalam hal ini adalah potongan harga yang diberikan oleh perusahaan diharapkan penjualan akan dapat ditingkatkan. Agar perusahaan dapat menggunakan harga secara efektif, hendaknya diadakan suatu perencanaan yang baik dengan memperhatikan segala faktor yang berkaitan dengan promosi dan kebijakan harga sehingga apa yang dilaksanakan dapat berhasil dengan baik.

Kualitas produk adalah kemampuan suatu produk untuk melaksanakan fungsinya meliputi, daya tahan keadaan, ketepatan kemudahan operasi dan perbaikan, serta atribut bernilai lainya. Untuk meningkatkan kualitas produk perusahaan dapat menerapkan program TQM. Selain mengurangi kerusakan produk, tujuan pokok kualitas total adalah untuk meningkatkan nilai konsumen.

Citra merek, persepsi harga dan kualitas produk merupakan salah satu atribut produk yang dapat mempengaruhi tingkat penjualan suatu produk, karena dari atribut tersebut yang dapat membedakan kelebihan dan kelemahan produk yang satu dengan yang lainnya. Dan dengan adanya atribut ini juga dapat memberikan pengetahuan kepada masyarakat mengenai ukuran tingkat kualitas produk yang akan digunakan dan konsumen mendapatkan kebebasan dalam memilih barang atau jasa yang sesuai dengan kebutuhannya.

Berdasarkan uraian diatas, maka penulis tertarik untuk melakukan penelitian dengan judul : "PENGARUH CITRA MEREK, PERSEPSI HARGA DAN KUALITAS PRODUK TERHADAP KEPUTUSAN 


\section{PEMBELIAN KONSUMEN NPK MUTIARA DI UD. BARELANG TANI JAYA BATAM".}

\subsection{Rumusan Masalah}

Atas dasar uraian diatas, maka penting kiranya melakukan penelitian yang akan membahas tentang beberapa faktor yang dapat mempengaruhi keputusan pembelian produk NPK Mutiara di UD.Barelang Tani Jaya Batam, antara lain faktor Citra Merek, Persepsi Harga dan Kualitas Produk sebagai objek penelitian, menerapkan faktor-faktor tersebut dalam mendorong keputusan pembelian konsumen NPK Mutiara di UD.Barelang Tani Jaya Batam. Berdasarkan rumusan masalah tersebut, maka dapat dirumuskan pertanyaan penelitian sebagai berikut :

1.Apakah citra merek berpengaruh terhadap keputusan pembelian konsumen NPK Mutiara di UD.Barelang Tani Jaya Batam?

2.Apakah persepsi harga berpengaruh terhadap keputusan pembelian konsumen NPK Mutiara di UD.Barelang Tani Jaya Batam?

3.Apakah kualitas produk berpengaruh terhadap keputusan pembelian konsumen NPK Mutiara di UD.Barelang Tani Jaya Batam?

4.Apakah citra merek, persepsi harga dan kualitas produk secara simultan berpengaruh terhadap keputusan pembelian konsumen NPK Mutiara di UD.Barelang Tani Jaya Batam?

\section{TELAAH PUSTAKA}

\subsection{Landasan Teori}

\subsubsection{Pengertian Pemasaran}

Pemasaran merupakan ujung tombak perusahaan. Dalam dunia persaingan yang semakin ketat, perusahaan dituntut agar tetap bertahan hidup dan berkembang. Oleh karena itu seorang tenaga pemasar dituntut memahami permasalahan pokok dibidangnya dan menyusun strategi agar dapat mencapai tujuan perusahaan. Berikut ini adalah beberapa pengertian mengenai pemasaran:

Pengertian pemasaran atau marketing adalah kegiatan manusia yang diarahkan untuk memenuhi kebutuhan dan keinginan melalui proses pertukaran. Banyak yang menanggap bidang ini identik atau sama dengan penjualan.

Pemasaran menurut Kotler dan Amstrong dalam Ian Antonius Ong dan Drs. Sugiono Sugiharto, MM (2013): Pemasaran adalah proses dimana perusahaan menciptakan nilai bagi pelanggan dan membangun hubungan yang kuat dengan pelanggan, dengan tujuan menangkap nilai dari pelanggan sebagai imbalannya. Pengertian di atas memperlihatkan adanya suatu usaha untuk memenuhi kebutuhan serta adanya suatu usaha yang diarahkan untuk memperoleh kebutuhan tersebut dengan cara mengadakan hubungan dengan pihak lain.Dari dua defininsi ahli diatas dapat disimpulkan bahwa pemasaran merupakan suatu proses sosial dan manajerial. Definisi sosial menunjukkan peran yang dimainkanoleh pemasaran di masyarakat. Seorang pemasar mengatakan bahwa peran pemasaran adalah menghasilkan standart yang lebih tinggi. 


\subsubsection{Keputusan Pembelian}

Dalam pemasaran, kita tidak bisa lepas dari pengarahan perilaku konsumen, seringkali kebutuhan konsumen ini tidak terpenuhi dan ia akan menunjukkan perilaku yang gembira sebagai manifestasi rasa puasnya.

"Perilaku konsumen adalah tindakan-tindakan proses dalam hubungan sosial yang dilakukan oleh individu, kelompok dan organisasi dalam mendapatkan penggunaan suatu produk lainnya sebagai suatu akibat dari pengalamannya dengan produk dan sumber-sumber lainnya”. Menurut Kotler dalam Angga Yudha (2012) keputusan pembelian adalah suatu proses pengambilan keputusan dalam membeli suatu produk yang dimulai dari pengenalan masalah, pencarian informasi, penilaian alternatif, membuat keputusan pembelian dan akhirnya didapatkan perilaku setelah membeli yaitu puas atau tidak puas atas suatu produk yang dibelinya.

Dalam keputusan pembelian dengan membeli produk atau merek yang paling disukai, ada 2 faktor yang muncul antara niat dalam membuat keputusan untuk membeli. Faktor adalah sikap orang lain dan yang kedua faktor situasi yang tidak diharapkan.

Setelah membeli produk, konsumen akan mengalami proses kepuasan sebagai tingkah laku paska pembelian yaitu suatu perasaan senang atau kecewa seseorang yang berasal dari perbandingan antara kesannya terhadap kinerja atau hasil suatu produk dan harapannya. Jika kinerja berada dibawah harapan, konsumen tidak puas. Jika kinerja memenuhi harapan konsumen, maka akan menimbulkan kepuasan dan senang.

Pengertian pembeli adalah kegiatan individu atau organisasi dalam mendapatkan barangatau jasa dengan terlebih dahulu mempertimbangkan banyak faktor yang mempengaruhi barang atau jasa tersebut serta biasanya pembelian dilakukan dengan alat tukar uang.

\subsubsection{Citra Merek}

Secara legal formal, merek diatur secara tersendiri dalam perundangundangan hak atas kekayaan intelektual atau HAKI, khususnya Undang-Undang Republik Indonesia No.15 Tahun 2001. Karena didalam era perdangangan global, sejalan dengan konvensi-konvensi internasional yang telah diratifikasi Indonenesia, peranan merek menjadi sangat penting terutama dalam menjaga persaingan usaha yang sehat.

Semua produk dengan merek tertentu menawarkan keunggulannya, baik melalui kegunaan, kemanjuran, fasilitas, fasilitas dan sebagainya.Semua penawaran atas produk-produk tersebut dikemas sedemikian menarik, sehingga konsumen "terbujuk" untuk membelinya. Brand merupakan salah satu asset perusahaan yang tidak berwujud (intangible asset) yang semakin mahal harganya, karena brand tersebut dapat mempengaruhi omset penjualan perusahaan.Sedemikian besar pengaruh brand tersebut sering mengalami perubahan nilai menjadi berlipat-lipat ganda dari nilai bisnis sesungguhnya. Akibatnya brand sering dibeli dan dijual dengan harga yang sangat tinggi, yang sebenarnya tidak hanya menggambarkan asset tak berwujud (intangible asset)milik perusahaan belaka, tetapi menggambarkan tingkat penjualan merekdimasa depan yang dapat diperkirakan. 
Istilah image mulai popular sejak tahun 1950-an, yang dikemukakan dalam berbagai konteks seperti image terhadap organisasi, image terhadap perusahaan, image nasional, image terhadap merek atau brand image, image publis, dan self image.

Citra merek menurut Kotler dan Keller (2010) adalah persepsi konsumen tentang suatu merek sebagai refleksi dari asosiasi yang ada pada pikiran konsumen. Citra merek merupakan asosiasi yang muncul dalam benak konsumen ketika mengingat suatu merek tertentu. Asosiasi tersebut secara sederhana dapat muncul dalam bentuk pemikiran dan citra tertentu yang dikaitkan dengan suatu merek.

Citra ini tidak dapat dicetak seperti mencetak barang di pabrik, tetapi citra ini adalah kesan yang diperoleh sesuai dengan pengetahuan pemahaman seseorang tentang sesuatu. Citra terbentuk dari bagaimana perusahaan melaksanakan kegiatan operasionalnya, yang mempunyai landasan utama pada segi layanan. Jadi image ini akan diperhatikan publik dari waktu ke waktu dan akhirnya akan membentuk suatu pandangan positif yang akan dikomunikasikan dari satu mulut ke mulut lain.

\subsubsection{Persepsi Harga}

Harga adalah salah satu faktor penting dari sisi penyedia jasa untuk memenangkan suatu persaingan dalam memasarkan produknya. Oleh karena itu harga harus ditetapkan. Harga juga merupakan uang yang harus dibayar pelanggan untuk produk itu. Menurut definisi diatas, kebijakan mengenai harga sifat hanya sementara, berarti produsen harus mengikuti perkembangan harga dipasar dan harus mengetahui posisi perusahaan dalam situasi pasar secara keseluruhan.Menurut Kotler dan Armstrong dalam Desy Irana, Dewi Lubis dan Rahmat Hidayat (2017), harga adalah sejumlah uang yang dibebankan atas suatu barang atau jasa atau jumlah dari nilai uang yang ditukar konsumen atas manfaat manfaat karena memiliki atau menggunakan produk atau jasa tersebut.Harga juga sangat mempengaruhi tingkat penjualan sutu produk yang dipasarkan.

Alasan ekonomis akan menunjukkan harga yang rendah atau harga yang terlalu berkompetisi merupakan salah satu pemicu penting untuk meningkatkan kinerja pemasaran, tetapi alasan psikologis dapat menunjukkan bahwa harga justru merupakan indikator kualitas karena itu dirancang sebagai salah satu instrumen penjualan sekaligus sebagai instrumen kompetisi yang menentukan tingkat penjualan.

Harga memiliki pengaruh yang signifikan terhadap keberhasilan perusahaan, karena keuntungan perusahaan tergantung dari keuntungan tiap unit yang terjual.Harga juga bisa mempengaruhi persepsi pelanggan, harga yang rendah dapat memberikan persepsi murahan, produk berkualitas rendah, sedangkan harga yang lebih tinggi mengesankan kualitas produk yang lebih baik.Menurut Shichiffman dan Kanuk dalam Wifki Muharam dan Euis Soliha (2017) persepsi merupakan suatu proses seseorang individu dalam menyeleksi, mengorganisasikan, dan menterjemahkan stimulus informasi yang datang menjadi suatu gambaran yang menyeluruh, persepsi harga ialah bagaimana cara konsumen melihat harga sebagai harga yang tinggi, rendah dan adil. Hal ini mempunyai pengaruh yang kuat baik kepada minat beli dan kepuasan dalam pembelian. 
Disamping itu harga merupakan unsur bauran pemasaran yang bersifat fleksibel, artinya dapat diubah dengan cepat, berbeda halnya dengan karakteristik produk atau komitmen terhadap saluran distribusi.

\subsubsection{Kualitas Produk}

Demikian juga konsumen dalam membeli suatu produk, konsumen selalu berharap agar barang yang dibelinya dapat memuaskan segala keinginan dan kebutuhannya.Untuk itu perusahaan harus memenuhi keinginan konsumen, sehingga perusahaan dapat menciptakan produk yang sesuai dengan harapan konsumen.Kualitas produk yang baik merupakan sebuah harapan konsumen yang harus dipenuhi oleh perusahaan, karena kualitas produk yang baik merupakan kunci perkembangan produktivitas perusahaan.

Kotler dan Keller yang dialih bahasakan oleh Bob Sabran (2012), menyatakan bahwa kualitas produk adalah kemampuan suatu barang untuk memberikan hasil atau kinerja yang sesuai bahkan melebihi dari apa yang diinginkan pelanggan.

Indikator kualitas produk sebagai berikut:

\section{Performance (kinerja)}

Berhubungan dengan karakteristik operasi dasar dari sebuah produk.

\section{Durability (daya tahan)}

Yang berarti berapa lama umur produk yang bersangkutan bertahan

sebelum produk tersebut harus diganti. Semakin besar frekuensi pemakaian konsumen terhadap produk, maka akan semakin besar pula daya produk.

3.Conformance to specification (kesesuaian dengan spesifikasi)

Yaitu sejauh mana karakteristik operasi dasar dari sebuah produk

memenuhi spesifikasi tertentu dari konsumen atau tidak ditemukannya cacat pada produk.

4. Features (fitur)

Karakteristik produk yang dirancang untuk menyempurnakan fungsi produk atau menambah ketertarikan konsumen terhadap produk.

\section{Realibility (reabilitas)}

Adalah probabilitas bahwa produk akan bekerja dengan memuaskan atau tidak dalam periode waktu tertentu.

Semakin kecil kemungkinan terjadinya kerusakan, maka produk tersebut dapat diandalkan.

6. Aesthetics (estetika)

Berhubungan dengan bagaimana dengan penampilan produk.

7. Perceived quality (kesan kualitas)

Sering dibilang merupakan hasil penggunaan pengukuran yang

dilakukan secara tidak langsung karena terdapat kemungkinan bahwa konsumen tidak mengerti atau kekurangan informasi atas produk yang bersangkutan.

\section{Serviseability}

Meliputi kecepatan dan kemudahan untuk direparasi serta kompetensi serta keramahtamahan staff layanan.

Kualitas harus dimulai dari kebutuhan pelanggan dan berakhir pada persepsi pelanggan. Hal ini berarti bahwa citra kualitas yang baik bukan berdasarkan sudut pandang atau persepsi pihak penyedia jasa, melainkan berdasarkan sudut pandang 
atau persepsi pelanggan.Pelangganlah yang menentukan berkualitas atau tidaknya suatu produk atau jasa.Dengan demikian baik tidaknya kualitas tergantung pada kemampuan penyedia produk atau jasa dalam memenuhi harapan pelanggannya secara konsisten.

\subsection{Kerangka Pemikiran}

\section{Gambar 2.1 Kerangka Pemikiran}

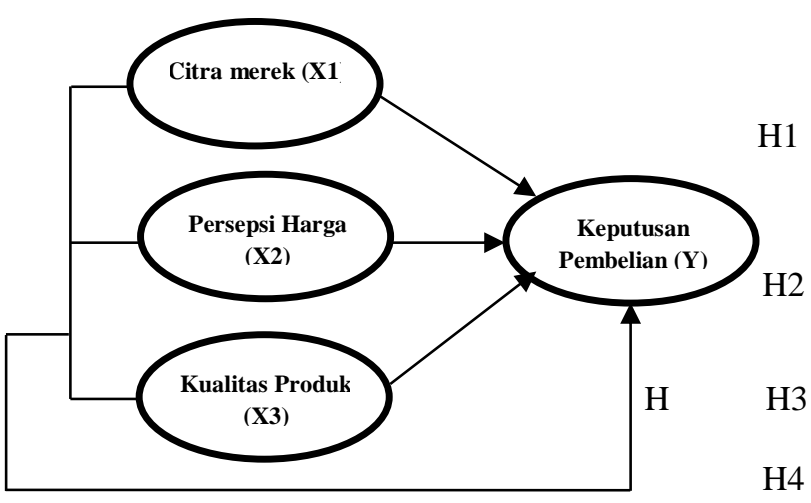

\subsection{Hipotesis Penelitian}

Berdasarkan landasan teori dan kerangka pemikiran sebagaimana dijelaskan diatas, dapat dibuat hipotesis sebagai berikut:

1. H1: Diduga citra merek berpengaruh signifikan terhadap keputusan pembelian konsumen NPK Mutiara di UD.Barelang Tani Jaya Batam.

2. H2: Diduga persepsi harga berpengaruh signifikan terhadap keputusan pembelian konsumen NPK Mutiara di UD. Barelang Tani Jaya Batam.

3. H3: Diduga kualitas produk berpengaruh signifikan terhadap keputusan pembelian konsumen NPK Mutiara di UD. Barelang Tani Jaya Batam.

4. H4: Diduga citra merek, persepsi harga, dan kualitas produk secara simultan berpengaruh signifikan terhadap keputusan pembelian konsumen NPK Mutiara di UD. Barelang Tani Jaya Batam.

\section{METODE PENELITIAN}

\subsection{Teknik Pengumpulan Data}

Metode pengumpulan data dalam penelitian ini dilakukan dengan cara :

1. Wawancara

Menurut Sugiyono (2016) wawancara digunakan sebagai teknik pengumpulan data apabilia peneliti ingin melakukan studi pendahuluan untuk menemukan perusahaan yang baru diteliti, dan juga peneliti ingin mengetahui hal-hal dari responden yang ingin mengetahui hal-hal dari responden yang lebih mendalam dan jumlah respondennya sedikit/kecil.

2. Kuesioner

Menurut Sugiyono (2016) kuesioner merupakan teknik pengumpulan data yang dilakukan dengan cara memberi seperangkat pertanyaan atau pernyataan tertulis kepada responden untuk dijawabnya. Kuesioner merupakan teknik 
pengumpulan data yang efisien bila peneliti tahu dengan pasti variabel yang akan diukur dan tahu apa yang bisa diharapkan dari responden. Selain itu, kuesioner juga cocok digunakan bila jumlah responden cukup besar dan tersebar di wilayah yang luas

\section{Observasi}

Menurut Sugiyono (2016) observasi sebagai teknik pengumpulan data mempuyai ciri yang spesifik bila dibandingkan dengan teknik yang lain, yaitu wawancara dan kuisioner. Kalau wawancara dan kuisioner selalu berkomunikasi dengan orang, maka observasi tidak terbatas pada orang, tetapi juga obyek-obyek alam yang lain.

\subsection{Teknik Analisis Data}

\subsubsection{Uji Statistik Deskriptif}

Statistik deskriftif digunakan untuk menganalisis data dengan cara menggambarkan data yang terkumpul namun bukan membuat kesimpulan yang bersifat generalisasi.

\subsubsection{Uji Kualitas Data}

\subsubsection{Uji Validitas}

Azwar dalam Wibowo (2012) menyatakan, uji validitas yaitu uji yang dimaksudkan untuk mengetahui sejauh mana alat pengukur itu mampu mengukur apa yang ingin diukur. Dalam menetukan kelayakan dan tidaknya suatu item yang akan digunakan biasanya dilakukan uji signifikasi koefisien korelasi pada taraf 0,05 artinya suatu item dianggap memiliki tingkat keberterimaan atau valid jika memiliki korelasi signifikan terhadap skor total item. Azwar dalam Agung (2012), menyatakan jika suatu item memiliki nilai capaian koefisien korelasi minimal 0,30 dianggap memiliki daya pembeda yang cukup memuaskan atau dianggap valid.

\subsubsection{Uji Reliabilitas}

Azwar dalam Wibowo (2012) menyatakan reliabilitas adalah istilah yang dipakai untuk menunjukkan sejauh mana suatu hasil pengukuran relatif konsisten apabila pengukuran diulangi dua kali atau lebih.Reliabilitas juga dapat berarti indeks yang menunjukkan sejauh mana alat pengukur dapat menunjukkan dapat dipercaya atau tidak.Uji ini digunakan untuk mengetahui dan mengukur tingkat konsistensi alatukur.Wibowo (2012) menyatakan ada beberapa metode yang digunakan untuk menguji reliabilitas.Namun metode uji yang paling sering digunakan dan begitu umum untuk uji instrumen pengumpulan data yaitu metode Cronbach's Alpha.

a) Cronbach Alpha > 0,6 maka instrumen pengamatan dinyatakan reliabel.

b) Cronbach Alpha < 0,6 maka instrumen pengamatan tidak reliabel.

\section{HASIL PENELITIAN DAN PEMBAHASAN}

\subsection{Pengujian Data}

\subsubsection{Deskripsi Responden}

Deskripsi responden yang dilakukan dalam penelitian ini bertujuan memberikan deskripsi mengenai karakter responden yaitu konsumen atau 
pengunjung UD. Barelang Tani Jaya Buana Niaga Batam yang telah mengisi kuesioner dalam penelitian ini, sebanyak 58 orang yang telah ditetapkan peneliti sebagai sebuah sampel. Gambaran umum karakteristik responden dalam tabel berikut ini diuraikan persentase responden tersebut yang mencakup jenis kelamin, tingkat pendidikan, usia, dan pekerjaan. Data tersebut kemudian diproses dengan menggunakan program Statistical Package for the Social Scienses (SPSS). Adapun hasil karakteristik responden yang diolah dari hasil penyebaran kuesioner adalah sebagai berikut:

\subsubsection{Uji Reliabilitas}

Untuk mengetahui reliabilitas variabel Citra Merek (brand image), harga, kualitas produk, dan keputusan pembelian, maka digunakan nilai Cronbach's Alpa diatas 0,60. Uji reliabilitas menggunakan SPSS versi 20 dengan memberikan fasilitas pengukuran Cronbach's Alpa (a). Apabila hasil koefisien Alpa lebih besar dari taraf signifikan 60\% atau 0,6, maka kuesioner reliabel. Apabila hasil koefisien Alpa lebih kecil dari 60\% atau 0,6 maka kuesioner tidak reliabel. Dalam tabel berikut ini menyajikan ukuran reliabilitas dari seluruh variabel penelitian.

Tabel 4.1

Hasil Pengujian Reliabilitas

\begin{tabular}{|c|l|l|c|c|c|}
\hline No & Variabel & $\begin{array}{c}\text { Nof } \\
\text { Item }\end{array}$ & $\begin{array}{c}\text { Cronbach's } \\
\text { Alpa }\end{array}$ & Keterangan \\
\hline 1 & $\begin{array}{l}\text { Citra } \\
\text { Merek } \\
\text { (Brand } \\
\text { Image) }\end{array}$ & 6 & 0,657 & Reliabel \\
\hline 2 & $\begin{array}{l}\text { Persepsi } \\
\text { Harga }\end{array}$ & 12 & 0,884 & Reliabel \\
\hline 3 & $\begin{array}{l}\text { Kualitas } \\
\text { Produk }\end{array}$ & 16 & 0,894 & Reliabel \\
\hline 4 & $\begin{array}{l}\text { Keputusan } \\
\text { Pembelian }\end{array}$ & 6 & 0,834 & Reliabel \\
\hline
\end{tabular}

Sumber : Hasil Pengolahan Data Peneliti, 2019

Dari tabel diatas terlihat bahwa Cronbach's Alpa lebih besar dari 0,60, dan hal ini menunjukkan bahwa setiap butir pernyataan dalam kuesioner handal atau reliable. Atau dengan kata lain, semua butir pernyataan yang digunakan adalah stabil dan konsistensi dalam mengukur masing-masing variabel penelitian. 


\subsubsection{Uji Asumsi Klasik \\ 4.1.2.1 Uji Normaitas Data}

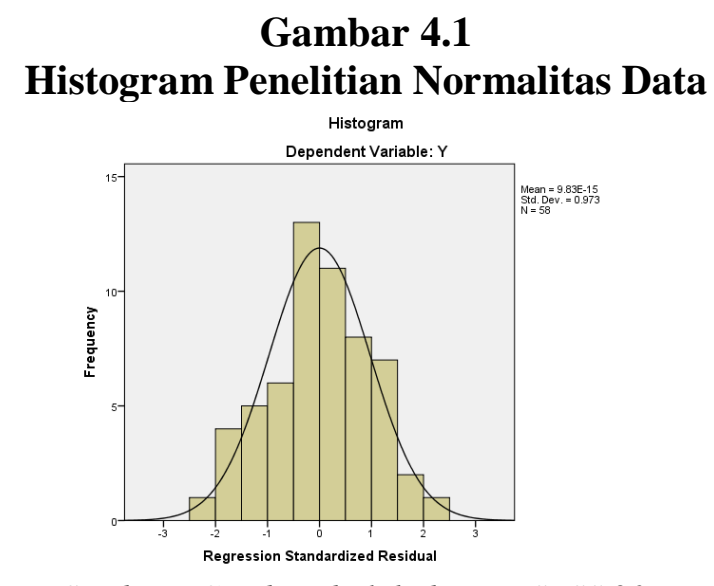

Sumber : Gambar diolah dengan SPSS 20

Dalam gambar diatas dapat dilihat bahwa variabel Y (keputusan pembelian) berdistribusi mendekati normal, hal ini ditunjukkan oleh distribusi data yang tidak menceng ke kanan dan ke kiri.

\section{Gambar 4.2}

\section{Grafik PP-Plot Uji Normalitas Data}

Normal P-P Plot of Regression Standardized Residual

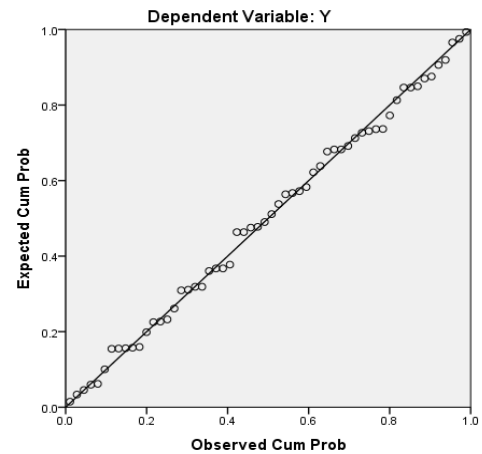

Sumber : Gambar diolah dengan SPSS 20

Dari gambar diatas disdapatkan hasil bahwa semua data berdistribusi secara normal, penyebaran data disekitar garis diagonal. Suatu variabel dapat dikatakan normal jika gambar distribusi titik-titik (point-point) data menyebar disekitar garis diagonal dan penyebaran titik-titik (point-point) data searah atau mengikuti garis diagonal.

\subsubsection{Uji Heteroskedestisitas}

Pengujian heteroskedestisitas bertujuan untuk menguji apakah dalam model regresi terjadi ketidaksamaan variance dari residual satu pengamatan ke pengamatan lain. Jika varian dari residual satu pengamatan ke pengamatan lain tetap, maka disebut homokedestisitas, dan jika berbeda disebut heteroskedestisitas. Pada model yang baik tidak terjadi heteroskedestisitas. 


\section{Gambar 4.3}

\section{Hasil Pengujian Heteroskedestisitas}

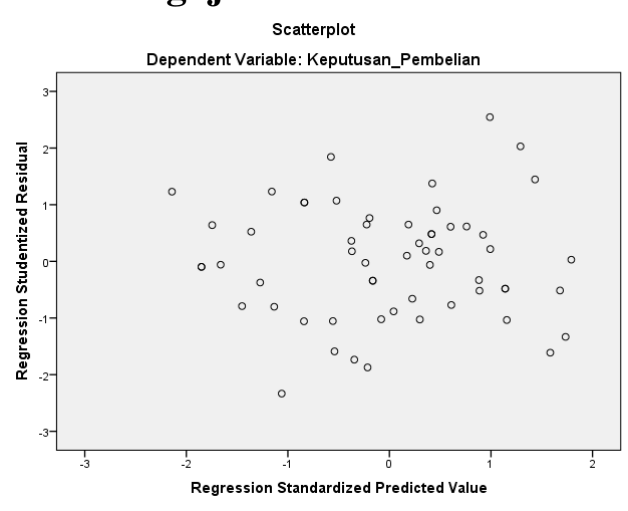

Sumber : Gambar diolah dengan SPSS 20

Dari gambar diatas dapat dilihat bahwa titik-titik (point-point) tidak menunjukkan suatu pola tertentu, namun menyebar secara merata diantara angka 0 pada sumbu Y..

\subsubsection{Uji Multikolinearitas}

Untuk mendeteksi ada atau tidaknya Miltikolinearitas di dalam model regresi, salah satu caranya adalah dengan melihat besarnya nilai tolerance dan Vaiable Inflation Factor (VIP). Uji Miltikolinearitas dapat dinilai melalui nilai VIF (Vaiable Inflation Factor) disekitar angka 1 dan kurang dari 10 dan nilai tolerance nya mendekati 1 atau tidak kurang dari 0,10. Dari hasil penelitian ini ditemukan bahwa Variabel citra merek nilainya sebesar 0,114 > 0,10 dan VIF sebesar 8,781 < 10 , variabel persepsi harga adalah sebesar 0,198 > 0,10 dan VIF sebesar 5,041 $<10$ dan variabel kualitas produk adalah sebesar 0,114 > 0,10 dan VIF sebesar 8,806 $<10$, sehingga dapat dinyatakan pada model penelitian ini tidak terdapat masalah multikolinearitas atau bebas multikolinearitas antara variabel bebas karena nilai tolerance berada dibawah 1 dan nilai VIF masih dibawah angka 10.

\subsubsection{Uji Hipotesis}

\subsubsection{Uji T}

Uji T digunakan untuk menguji seberapa jauh tingkat signifikansi pengaruh variabel independen (citra merek, persepsi harga dan kualitas produk) dalam mempengaruhi variabel dependen (keputusan pembelian) secara parsial. Pengujian signifikan koefisien korelasi parsial dan koefisien regresi secara parsial dilakukan dengan melihat taraf signifikansi, jika taraf signifikansi yang dihasilkan dari perhitungan dibawah 0,05 , maka hipotesis ditolak atau yang berarti bahwa terdapat pengaruh yang positif dan signifikan antara variabel X dan Y. Persamaan rumusnya adalah sebagai berikut :

$\mathbf{H}_{\mathbf{0}} \quad$ = Variabel $\mathrm{X}$ tidak berpengaruh terhadap variabel $\mathrm{Y}$

$\mathbf{H}_{1}=$ Variabel $\mathrm{X}$ berpengaruh terhadap variabel $\mathrm{Y}$

Kaidah pengambilan keputusan dalam pengujian ini adalah :

1. Jika $\mathbf{t}_{\text {hitung }}>\mathbf{t}_{\text {tabel }}$ dan nilai Signifikan $<0,05$, maka $\mathbf{H}_{\mathbf{0}}$ ditolak $\mathbf{H}_{\mathbf{1}}$ diterima, jadi variabel independen $(\mathrm{X})$ berpengaruh signifikan terhadap variabel dependen (Y). 
2. Jika $\mathbf{t}$ hitung $<\mathbf{t}$ tabel dan nilai Signifikan $>0,05$, maka $\mathbf{H}_{\mathbf{0}}$ diterima $\mathbf{H}_{\mathbf{1}}$ ditolak, jadi variabel independen $(\mathrm{X})$ tidak berpengaruh signifikan terhadap variabel dependen (Y).

Hasil pengujian data:

1. Terdapat pengaruh positif dan signifikan variabel Citra Merek (Brand Image) (X1), hal ini dikarenakan nilai $\mathbf{t}$ hitung 9,962 > t tabel 1,672 dan tingkat signifikannya adalah $0,000<0,05$ maka demikian $\mathrm{H} 0$ ditolak dan Ha diterima, artinya terdapat pengaruh yang positif dan signifikan antara variabel Citra Merek (X1) terhadap variabel keputusan pembelian (Y).

2. Terdapat pengaruh positif dan signifikan pada variabel Persepsi Harga (X2), hal ini dikarenakan nilai $\mathbf{t}$ hitung 52,693 $>\mathbf{t}$ tabel 1,672 dan tingkat signifikannya adalah $0,000<0,05$ maka demikian Ho ditolak dan Ha diterima, artinya terdapat pengaruh yang positif dan signifikan antara variabel persepsi harga (X2) terhadap variabel keputusan pembelian (Y).

3. Terdapat pengaruh positif dan signifikan pada variabel Kualitas Produk (X3), hal ini dikarenakan nilai $\mathbf{t}$ hitung 40,089 > t tabel 1,672 dan tingkat signifikannya adalah 0,000 $<0,05$ maka demikian Ho ditolak dan Ha diterima, artinya terdapat pengaruh yang positif dan signifikan antara variabel kualitas produk (X3) terhadap variabel keputusan pembelian (Y).

\subsubsection{Uji F}

Uji F dilakukan untuk menguji adakah pengaruh secara bersama-sama (simultan) antara tiap-tiap variabel independen dengan variabel dependen. Kriteria yang digunakan adalah :

a. Jika probabilitas $>0,05$ maka $\mathrm{H} 0$ diterima.

b. Jika probabilitas < 0,05 maka H0 ditolak.

Kaidah pengambilan keputusan dalam pengujian ini adalah :

1. Jika $\mathbf{F}$ hitung $>\mathbf{F}$ tabel dan nilai signifikan $<0,05$ maka $\mathbf{H}_{\mathbf{0}}$ ditolak $\mathbf{H}_{\mathbf{1}}$ diterima, jadi variabel independen $(\mathrm{X})$ berpengaruh signifikan terhadap variabel dependen $(\mathrm{Y})$.

2. Jika $\mathbf{F}$ hitung $<\mathbf{F}$ tabeldan nilai signitifikan $>0,05$ maka $\mathbf{H}_{\mathbf{0}}$ diterima $\mathbf{H}_{\mathbf{1}}$ ditolak, jadi variabel independen $(\mathrm{X})$ tidak berpengaruh signifikan terhadap variabel dependen (Y).

Hasil Pengujian Data:

Hasil perhitungan menghasilkan bahwa $F_{\text {hitung }} 22017.692>2,17 \mathrm{~F}$ tabel dan nilai signifikansi yang terdapat pada tabel ANNOVA adalah 0,000, yang berarti nilai tersebut lebih kecil dari 0,05 maka dapat diketahui bahwa nilai tersebut menyatakan H0 ditolak, dan mengindikasikan terdapat pengaruh antara ketiga variabel yang diteliti, yaitu Citra Merek (X1), Persepsi Harga (X2), Kualitas Produk (X3), dan Keputusan Pembelian (Y).

\subsubsection{Uji Kefisien Determinasi}

Pada uji $\mathrm{R}^{2}$ (Uji Koefisien Determinasi) ini menjelaskan seberapa besar variasi variabel independen (Citra Merek, Persepsi Harga, dan Kualitas Produk) 
terhadap varibel dependen (Keputusan Pembelian). Nilai koefisien determinasi adalah antara nol dan satu. Nilai R kaudrat yang kecil berarti kemampuan variabelvariabel independen dalam menjelaskan variasi variabel dependen sangat terbatas. Dari hasil penhujian data diketahui bahwa terdapat pengaruh dari Citra Merek, Persepsi Harga, dan Kualitas Produk terhadap Keputusan Pembelian. Angka pada Adjusted R square atau disebut juga sebagai koefisien determinasi adalah sebesar 0,999 atau sama dengan 99\%. Angka tersebut memiliki arti bahwa sebesar 99\% variabel keputusan pembelian dapat dijelaskan oleh variabel Citra Merek, Persepsi Harga, dan Kualitas Produk. Atau dengan kata lain, besarnya pengaruh variabel Citra Merek, Persepsi Harga, dan Kualitas Produk terhadap Keputusan Pembelian adalah sebesar $99 \%$ sedangkan sisanya, yaitu $1 \%$ harus dijelaskan oleh faktor lainnya, yang berasal dari luar model regresi tersebut.

\section{KESIMPULAN DAN SARAN}

\subsection{Kesimpulan}

Berdasarkan hasil penelitian dan pembahasan yang telah dilakukan pada bab sebelumnya mengenai hubungan citra merek (brand image), persepsi harga, dan kualitas produk terhadap keputusan pembelian konsumen NPK Mutiara di UD. Barelang Tani Jaya Batam, maka dapat ditarik kesimpulan sebagai berikut ;

1. Variabel Citra Merek

Variabel citra merek secara individual memiliki pengaruh positif dan signifikan terhadap variabel keputusan pembelian, dikarenakan nilai $\mathbf{t}$ hitung $9,962>\mathbf{t}$ tabel 1,672 dan tingkat signifikannya adalah $0,000<0,05$. Berdasarkan kriteria diatas, citra merek memiliki peran penting dalam mempengaruhi keputusan pembelian konsumen NPK Mutiara di UD. Barelang Tani Jaya Buana Impian Batam.

2. Variabel Persepsi Harga

Variabel persepsi harga secara individu berpengaruh positif dan signifikan terhadap variabel keputusan pembelian, hal ini dikarenakan nilai $\mathbf{t}$ hitung 52,693 $>\mathbf{t}$ tabel 1,672 dan tingkat signifikannya adalah $0,000<0,05$. Berdasarkan kriteria diatas, persepsi harga memiliki peran penting dalam mempengaruhi keputusan pembelian konsumen NPK Mutiara di UD. Barelang Tani Jaya Buana Impian Batam.

3. Variabel Kualitas Produk

Variabel kualitas produk secara individu berpengaruh positif dan signifikan terhadap variabel keputusan pembelian, hal ini dikarenakan nilai $\mathbf{t}$ hitung 40,089 $>\mathbf{t}$ tabel 1,672 dan tingkat signifikannya adalah $0,000<0,05$. Berdasarkan kriteria diatas, kualitas produk memiliki peran penting dalam mempengaruhi keputusan pembelian konsumen NPK Mutiara di UD. Barelang Tani Jaya Buana Impian Batam.

4. Penelitian ini membuktikan bahwa terdapat pengaruh secara simultan antara citra merek, persepsi harga, dan kualitas produk terhadap keputusan pembelian konsumen pada 58 sampel yang diteliti. Hal ini didapatkan dari hasil pengolahan yang menunjukkan bahwa $22017.692>2,17 \mathrm{~F}$ tabel dan nilai signifikansi yang terdapat pada tabel ANNOVA adalah 0,000 yang berarti nilai tersebut lebih kecil dari 0,05. 


\subsection{Saran}

Setelah mempelajari seluruh proses penelitian yang menyangkut seluruh permasalahan yang diuji, maka dapat diberikan saran sebagai berikut :

1. Bagi Perusahaan

a. Dalam hasil penelitian ini, citra merek (X1) memiliki pengaruh besar terhadap keputusan pembelian, sehingga penulis menyarankan kepada perusahaan untuk tetap menjaga nama baik citra merek pupuk NPK Mutiara supaya konsumen tetap percaya dan menjadikan pupuk NPK sebagai pupuk andalan kesuburan tanaman pertanian.

b. Dalam hasil penelitian ini, persepsi harga (X2) memiliki pengaruh besar terhadap keputusan pembelian, sehingga penulis menyarankan kepada perusahaan untuk mampu menetapkan harga produk sesuai dengan standart sehingga mendorong konsumen untuk memutuskan membeli produk.

c. Dalam hasil penelitian ini, kualitas produk (X3) memiliki pengaruh besar terhadap keputusan pembelian, sehingga penulis menyarankan kepada perusahaan untuk tetap menjaga keunggulan dan kualitas pupuk NPK Mutiara sehingga konsumen tidak memiliki keraguan untuk selalu membeli produk NPK dan merasa diuntungkan ketika menggunakan pupuk NPK.

2. Bagi Universitas atau Fakultas

Hasil penelitian ini dapat menjadi gambaran bagi fakultas atau seluruh mahasiswa/i mengenai hubungan dari beberapa bagian marketing mix terhadap keputusan pembelian, dan dapat menelusuri beberapa faktor (variabel) lain yang memiliki pengaruh lebih signifikan terhadap variabel lainnya.

3. Bagi Penulis Selanjutnya

Dalam skripsi ini, penulis menentukan 4 variabel, untuk peneliti selanjutnya dapat dikembangkan dengan variasi yang lebih banyak atau menggunakan korelasi variabel yang lain seperti variabel intervening atau moderating sehingga penelitian akan lebih menarik dari penelitian sebelumnya.

\section{DAFTAR PUSTAKA}

Alma, Buchari. (2013). Manajemen Pemasaran dan Pemasaran Jasa. Bandung: Alfabeta

Anas Affandi, Aldon Sinaga dan Ana Arifatus S (2014). Hubungan Pengetahuan Dan Persepsi Harga Dengan Penggunaan Pestisida Dalam Usahatani. Jurnal Agribisnis Indonesia. (Online). Vol 2, No 2.

(https://www.researchgate.net) (diakses 11 Januari 2019)

Angga Yudha (2012). Pengaruh Citra Merek, Persepsi Harga Dan Kualitas

Produk Terhadap Keputusan Pembelian Yi Action Camera Di Yogyakarta.

Skripsi. Yogyakarta: Universitas Muhammadyah

Yogyakatrahttp://repository.umy.ac.id) (diakses 16 Desember 2018)

Cornelia Dumarya Manik (2017). Pengaruh Penetapan Harga Terhadap Keputusan Pembelian Panel Listrik Pada Pt. Cakra Raya Teknologi Di Tangerang Kota. Jurnal Pemasaran Kompetitif. (Online). no. ISSN (cetak) 2598-0823, 
(file:///C:/Users/USER/Downloads/678-1142-1-SM.pdf) (diakses 16 Desember 2018)

Desy Irana, Dewi Lubis dan Rahmat Hidayat (2017). Pengaruh Citra Merek dan Harga Terhadap Keputusan Pembelian pada Sekolah Tinggi Ilmu Manajemen Sukma Medan. Jurnal Ilham (Online). Vol. 5, No. 1, (https://www.researchgate.net) (diakses 16 Desember 2018)

Ferdyanto Fure, Joyce Lapian dan Rita Taroreh (2015). Pengaruh Brand Image Kualitas Produk, dan Harga Terhadap Keputusan Pembelian Konsumen di J.CO Manado. (Online). Vol.3 No.1 (https://media.neliti.com) (diakses 11 Januari 2018)

Ian Antonius Ong dan Drs. Sugiono Sugiharto, MM (2013). Analisa Pengaruh Strategi Diferensiasi, Citra Merek, Kualitas Produk, dan Harga Terhadap Keputusan Pembelian Pelanggan di Cicao Station Surabaya. Jurnal Manajemen Pemasaran. (Online). Vol.1. No.2 (http://publication.petra.ac.id) (diakses 14 Desember 2018)

Ina Ratnasari \& Edi Suswardji (2016). Pengaruh Kualitas Produk Dan Citra Merek Terhadap Keputusan Pembelian Produk Fungisida Pt. Bayer Cropscience Pada Para Petani Di Kecamatan Rawamerta. (Online). Manajerial, Vol. 15 No.1 (http://ejournal.upi.edu/index.php/manajerial) (diakses 11 Januari 2019)

Joko Sudihartono (2009). Analisis Pengaruh Citra, Kualitas Layanan Dan Kepuasan Terhadap Loyalitas Pelanggan (Studi Kasus Pada Pt. Pupuk Kalimantan Timur, Sales Representative Kabupaten Grobogan). Tesis. Semarang: Program Studi Magister Manajemen Universitas Diponegoro (http://eprints.undip.ac.id) (diakses 11 Januari 2019)

Kotler, P dan Keller L. 2012. Manajemen Pemasaran, Jilid 1, Edisi ke-13, Alih Bahasa Bob Sabran, MM. Jakarta : Erlangga

Kotler, Philip dan Kevin L. Keller. 2010. Manajemen Pemasaran. Jilid 2, Edisi 13. Jakarta: Erlangga

Krystia Tambunan (2012). Analisis Pengaruh Citra Merek, Persepsi Kualitas, Dan Harga Terhadap Keputusan Pembelian Bandeng Presto (Studi Kasus Pada Konsumen Di Bandeng Presto Semarang). Skripsi. Semarang: Universitas Diponegoro (http://eprints.undip.ac.id) (diakses 09 Januari 2019)

May Margiyanto (2013). Analisis Pengaruh Citra Merek, Persepsi Harga, Kualitas Produk, Dan Promosi Terhadap Keputusan Pembelian Blackberry Di Kota Semarang. Skripsi. Semarang: Universitas Diponegoro (http://eprints.undip.ac.id) (diakses 09 Januari 2019)

Munalita Riamawahyu (2011). Pengaruh Produk, Harga Dan Promosi Terhadap Reaksi Konsumen Produk Pestisida Biotis Di Cv. Reka Sarana Sejahtera.

Skripsi. Semarang: Jurusan Manajemen Fakultas Ekonomi Universitas Negeri Semarang. (https://lib.unnes.ac.id) (diakses 11 Januari 2019)

Nela Evelina, Handoyo Djoko Waloejo, Sari Listyorin (2013), Pengaruh Citra Merek, Kualitas Produk, Harga dan Promosi Terhadap Keputusan Pembelian Kartu Perdana TelkomFlexi (Studi kasus pada konsumen TelkomFleksi di Kecamatan Kota Kudus Kabupaten Kudus). (Online). Vol.2.No.1 (http://ejournal3.unpid.ac.id) (diakses 14 Desember 2018) 
Nurul Fatmawati. A dan Euis Soliha (2017). Kualitas Produk, Citra Merek Dan Persepsi Harga Terhadap Proses Keputusan Pembelian Konsumen Sepeda Motor Matic "Honda". Jurnal Manajemen Teori dan Terapan. (Online). Tahun 10. No. 1 (https://e-journal.unair.ac.id) (diakses 16 Desember 2018).

Puger Harjuno (2017). Pengaruh Kualitas Produk, Persepsi Harga, Dan Citra Merek Terhadap Keputusan Pembelian Motor Matic Honda Scoopy (Studi Kasus Pada Mahasiswa Universitas Negeri Yogyakarta). Skripsi. Yogyakarta: Universitas Negri Yogyakarta (http://eprints.uny.ac.id) (diakses 9 Januari 2019).

Rika Ferawati (2017). Pengaruh Brand Image Terhadap Kesediaan Konsumen Membayar Harga Premium Produk Pizza Hut (Studi Kasus Konsumen Pizza Hut di Yogyakarta). Skripsi. Yogyakarta: Universitas Islam Indonesia (https://dspace.uii.ac.id) (diakses 16 Desember 2018)

Saladin Djaslim. (2012). Intisari Pemasaran dan Unsur-unsur Pemasaran. Bandung: Linda Karya

Suci Dwi Puspita (2015). Pengaruh Harga, Kualitas Produk, dan Citra Merek Terhadap Keputusan Pembelian Yoghurt (Survey pada konsumen Yoghurt Youjell PT. Insan Muda Berdikari), (Online). Vol.4, No.1(http://jurnal.unpad.ac.id) (diakses 10 Januari 2019)

Sunyoto, Danang. (2012). Konsep Dasar Riset Pemasaran dan Perilaku Konsumen. CAPS: Yogyakarta. 